\title{
Observations on the Relationship between the Formation of Photopigments and the Synthesis of Protein in Rhodopseudomonas spheroides
}

\author{
BY W. R. SISTROM \\ The Biological Laboratories, Harvard University, Cambridge 38, \\ Massachusetts, U.S.A.
}

(Received 30 October 1961)

\section{SUMMARY}

Cells of Rhodopseudomonas spheroides cannot increase their specific photopigment content in the absence of protein synthesis. The significance of this finding for an understanding of the structure of the photosynthetic apparatus in bacteria is discussed.

\section{INTRODUCTION}

Several years ago it was shown that in the non-sulphur purple bacteria the pigmentation of the cells is markedly influenced by oxygen and by the light intensity. When grown under highly aerobic conditions these bacteria contain only traces of bacteriochlorophyll and carotenoid pigments. When the bacteria are grown anaerobically in the light, the concentrations of the pigments in the cells depend upon the light intensity: the lower the intensity the greater the pigment concentrations. If the light intensity is suddenly reduced during growth, the differential rate of pigment synthesis (relative to the increase in turbidity of the culture) immediately increases and the pigment concentrations approach the values characteristic of the lower light intensity. On the other hand, if the light intensity is increased, pigment synthesis stops, and, since the culture continues to grow, the concentrations of the pigments fall to the values characteristic of this light intensity-pigment synthesis then recommences (Cohen-Bazire, Sistrom \& Stanier, 1957).

More recently it has become clear that more profound changes in cellular structure and metabolism accompany these variations in pigment content. Electron micrographs of light grown Rhodopseudomonas spheroides or Rhodospirillum rubrum show the cytoplasm to contain round, electron transparent structures which increase in number as the pigment content of the cell increases. These structures are not seen in micrographs of aerobically grown cells (Hickman \& Frenkel, 1959; Flexer, Sistrom \& Chapman, 1960). Newton (1960) has shown that pigmented cells of $\boldsymbol{R}$. rubrum contain antigens which are not present in aerobically grown cells. Similar observations have been made in this laboratory on $R$. spheroides. Lascelles (1959, 1960) has shown that marked changes in the activities of enzymes concerned in porphyrin biosynthesis are initiated when aerobically grown cells are transferred to photosynthetic conditions.

It seems reasonable then to think that changes in the amounts of photopigments involve much more than merely variations in the rates of synthesis of the pigments 
themselves. If this is true, one would expect to find some relationship between the synthesis of the pigments and of other cell components. In this paper one such relationship is described; it is shown that pigment synthesis is obligatorily coupled to protein synthesis.

\section{METHODS}

Rhodopseudomonas spheroides, strain Ga, has been used throughout. This strain is a mutant which differs from the wild-type in that it contains only neurosporene and hydroxyneurosporene in place of the array of carotenoid pigments of the wildtype (Griffiths \& Stanier, 1956). In some experiments a proline requiring mutant of strain Ga (Ga M7) was used. Both strains were obtained from Dr R. Y. Stanier.

Medium A of Sistrom (1960) was used. Succinic acid is the carbon source, and the medium is supplemented with glutamic acid and aspartic acid to give more rapid growth. This medium is termed AG Su. For experiments on the uptake of radioactive sulphate, the medium was made with ammonium chloride in place of ammonium sulphate and the sulphur supplied as sodium sulphate.

For photosynthetic growth the special culture vessels previously described were used (Cohen-Bazire et al. 1957). Recently, vessels constructed of lucite have also been used. These were $10 \mathrm{~cm}$. wide, $20 \mathrm{~cm}$. high and $2.5 \mathrm{~cm}$. thick. The cultures were incubated in aquaria at $34^{\circ}$. Light was provided by arrays of 300,150 or $75 \mathrm{~W}$. reflector flood lamps. The light intensity was measured at the entrance window of the aquarium with a Weston illumination meter calibrated in foot-candles. The cultures were aerated continuously with $5 \%$ carbon dioxide $(v / v)$ in either nitrogen or helium.

In some experiments it was necessary to have cultures with extremely low specific pigment concentrations, lower than result from growth in any reasonable light intensity. Such cultures were obtained in the following way, making use of the fact that aerobiosis stops pigment synthesis but does not destroy the pigments already present. A culture was first grown photosynthetically and its bacteriochlorophyll concentration measured; it was then diluted to give the bacteriochlorophyll concentration per unit volume called for. The diluted culture was placed under highly aerobic conditions and allowed to grow until the pigment concentration per cell reached the desired level. Such cultures were always pre-incubated anaerobically in the light before the start of the experiment.

Experience in this laboratory has shown that the relation between the optical density of a culture and its protein content varies with the conditions of growth. For this reason cell protein was determined directly.

Protein was estimated by the Folin-Lowry method (Lowry, Rosebrough, Farn \& Randall, 1951). Whole cells were digested in $1 \mathrm{~m}-\mathrm{NaOH}$ for $1-2 \mathrm{hr}$. at $40^{\circ}$ before analysis. Neither bacteriochlorophyll nor carotenoid pigments interfere with this determination.

Bacteriochlorophyll and carotenoid pigments were estimated from the optical densities at 775 and $468 \mathrm{~m} \mu$ of methanolic extracts (Cohen-Bazire, Sistrom \& Stanier, 1957).

\section{Radioactivity measurements}

Uniformly labelled $\mathrm{L}^{-14} \mathrm{C}$-phenylalanine was obtained from Nuclear-Chicago; ${ }^{35} \mathrm{~S}$ labelled sulphuric acid was obtained from Oak Ridge National Laboratory. 
The method used to determine the radioactivity of cell protein depended upon the specific activity expected. When the activity was low, a sample of the culture was added to one fifth its volume of ice-cold $50 \%$ trichloroacetic acid (TCA); after 15-20 min. in the cold the suspension was centrifuged, washed once with cold 5\% TCA, and resuspended in a small volume of water containing Dupanol C (200 $\mu \mathrm{g} .1$ ml.) (sodium lauryl sulphate obtained from E. I. DuPont, Inc., Wilmington, Delaware). A portion of this suspension was dried on a previously weighed planchet and the radioactivity determined. Corrections for self absorption were applied if necessary.

When the specific activity was high a more convenient procedure could be used. An equal volume of ice-cold 15\% TCA was added to the sample. After 15-20 min. in the cold a portion of this suspension, containing not more than $500 \mu \mathrm{g}$ of protein, was filtered through a 'Millipore' filter $(22 \mathrm{~mm}$. diam., $0.65 \mu$ pore size; Millipore Filter Corp., Watertown, Massachusetts). The filter was washed with cold $5 \%$ TCA and then with a little water, cemented to a planchet and the radioactivity determined.

The samples were counted with a thin-window Geiger tube; in every case a total of at least 1000 counts was recorded.

When cells were labelled with ${ }^{14} \mathrm{C}$-phenylalanine, treatment with boiling TCA removed only about $10 \%$ of the radioactivity in the cold TCA insoluble fraction. The more extensive washing procedure of Mandelstam (1958) failed to remove any further radioactivity and the cold TCA extraction described was therefore used routinely.

\section{RESULTS}

The experiments described below all demonstrate an obligatory coupling of pigment synthesis and protein synthesis. In each of these experiments cells initially deficient in photopigments are allowed to begin synthesis of these pigments and then protein synthesis is interrupted. They differ in the means used to obtain depigmented cells and to stop protein synthesis.

Experiment 1. In this experiment the cells were grown in bright light (5000 ft.c.) overnight, the culture was centrifuged and resuspended in the same medium containing phenylalanine ( $1 \mu \mathrm{g} . / \mathrm{ml}$.; 1485 c.p.m. $/ \mu \mathrm{g}$.) The culture was exposed to dim light (50 ft.c.) under anaerobic conditions. After $245 \mathrm{~min}$. chloromycetin was added to a final concentration of $50 \mu \mathrm{g} . / \mathrm{ml}$. The results of this experiment are shown in Fig. 1.

It is clear that the synthesis of both bacteriochlorophyll and carotenoid pigments and the uptake of phenylalanine stop at the same time. The specific content of bacteriochlorophyll at the time of addition of chloromycetin was $2 \cdot 2 \mu \mathrm{g}$. $/ 100 \mu \mathrm{g}$. of protein, which is a little less than one-third the value of $6 \cdot 5-7 \cdot 0$ eventually reached under these conditions.

Experiment 2. In this experiment the proline auxotroph (Ga M7) was used. A culture was grown in the usual medium supplemented with L-proline $(20 \mu \mathrm{g} . / \mathrm{ml}$.) under highly aerobic conditions. This culture was centrifuged, washed once and resuspended in proline-free medium and divided in two parts. At the start of the experiment, L-proline was added to give a concentration of $3 \mu \mathrm{g} . / \mathrm{ml}$. in one culture and of $10 \mu \mathrm{g} . / \mathrm{ml}$. in the other, and each received radioactive phenylalanine $(4 \mu \mathrm{g} . /$ 
ml.; 108 c.p.m. $/ \mu$ g.). The cultures were aerated with a gas mixture consisting of $5 \%$ $\mathrm{CO}_{2}, 5 \% \mathrm{O}_{2}$ and $90 \% \mathrm{~N}_{2}$. In these semi-aerobic conditions pigment synthesis begins immediately. The results are depicted in Fig. 2; it can be seen that these results are in accord with those of the first experiment. In the culture with $3 \mu \mathrm{g}$.

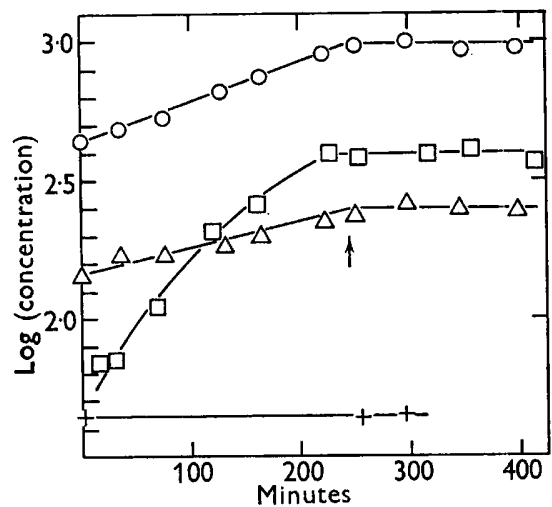

Fig. 1

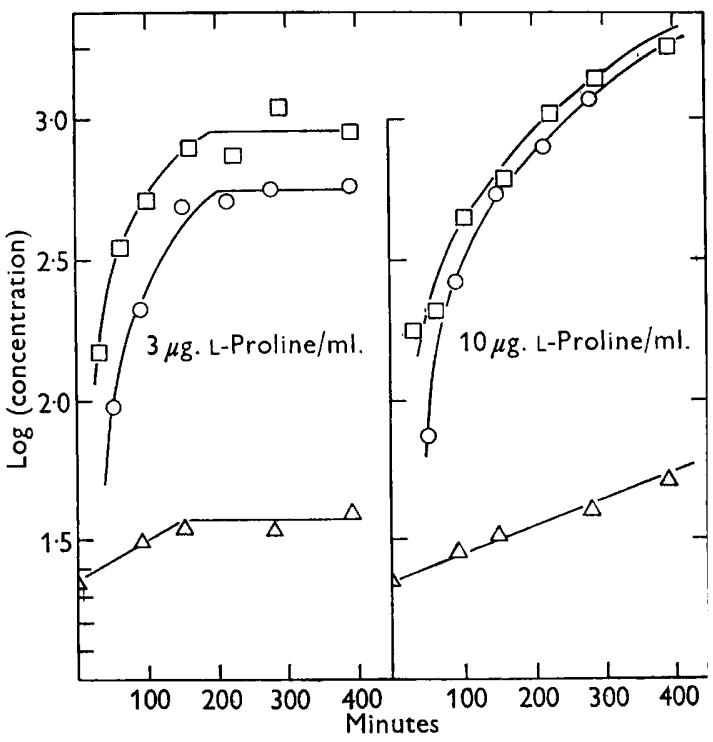

Fig. 2

Fig. 1. Inhibition of bacteriochlorophyll synthesis by chloromycetin. A culture of Rhodopseudomonas spheroides was grown photosynthetically in a light intensity of 5000 ft.c.; at the start of the experiment the intensity was reduced to $50 \mathrm{ft} . c$. At the time shown by the arrow chloromycetin was added to give a concentration of $50 \mu \mathrm{g} . / \mathrm{ml}$. Protein, $\mu \mathrm{g} . / \mathrm{ml}$. , + ; bacteriochlorophyll, $\mathrm{m} \mu \mathrm{g} . / \mathrm{ml} ., \mathrm{O}$; carotene, $\mathrm{m} \mu \mathrm{g} . / \mathrm{ml} ., \Delta$; phenylalanine, $\mathrm{m} \mu \mathrm{g} . / \mathrm{ml} ., \quad \square$.

Fig. 2. Requirement for proline for bacteriochlorophyll synthesis in proline auxotroph of Rhodopseudomonas spheroides. A culture of strain $\mathrm{Ga} \mathrm{M7}$ was grown aerobically in medium containing proline. At the start of the experiment it was divided into two parts and L-proline added to the concentrations shown. The cultures were incubated semiaerobically in the dark. Protein, $\mu \mathrm{g} . / \mathrm{ml} ., \Delta$; bacteriochlorophyll, $\mathrm{m} \mu \mathrm{g} . / \mathrm{ml}$., $\bigcirc$; phenylalanine, $\mathrm{m} \mu \mathrm{g} . / \mathrm{ml} ., \square$.

Table 1. Specific bacteriochlorophyll content and chromatophore protein of extracts of Rhodopseudomonas spheroides grown under different conditions

\begin{tabular}{|c|c|c|c|}
\hline \multirow[b]{2}{*}{ Growth conditions } & \multicolumn{2}{|c|}{$\begin{array}{c}\text { Specific bacteriochlorophyll } \\
\text { content ( } \mu \text { mole } / 100 \mathrm{mg} . \text { of } \\
\text { protein }) \\
\text { Fraction }\end{array}$} & \multirow{2}{*}{$\begin{array}{c}\% \text { total } \\
\text { protein in } \\
\text { chromatophore } \\
\text { fraction* }\end{array}$} \\
\hline & $\begin{array}{c}\text { Crude } \\
\text { extract }\end{array}$ & Chromatophore & \\
\hline $\begin{array}{l}\text { Photosynthetic: } \\
30 \mathrm{ft} . c . \\
12,000 \mathrm{ft} . c .\end{array}$ & $\begin{array}{l}7 \cdot 9 \\
0 \cdot 81\end{array}$ & $\begin{array}{r}11 \cdot 2 \\
1 \cdot 6\end{array}$ & $\begin{array}{l}60 \\
45\end{array}$ \\
\hline Aerobic & 0.004 & - & 50 \\
\hline
\end{tabular}

* This is the material sedimented after 1 hour in a centrifugal field of $100,000 \mathrm{~g}$. 
of L-proline per ml., uptake of phenylalanine and the synthesis of bacteriochlorophyll stop at about $200 \mathrm{~min}$. Synthesis of the carotenoid pigments also stops at this time, but this result is not included in the figure for the sake of simplicity.

Experiment 3. In this experiment protein synthesis was limited by allowing growth to exhaust the medium of sulphur. The culture used in this experiment was obtained by alternate photosynthetic and aerobic growth as described under Methods. The culture was washed once with sulphate-free medium and resuspended in the same medium. At zero time radioactive sulphate was added to give a final

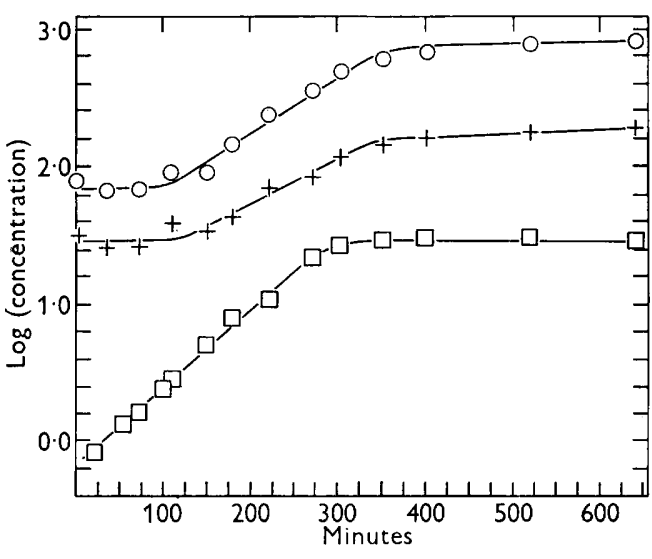

Fig. 3

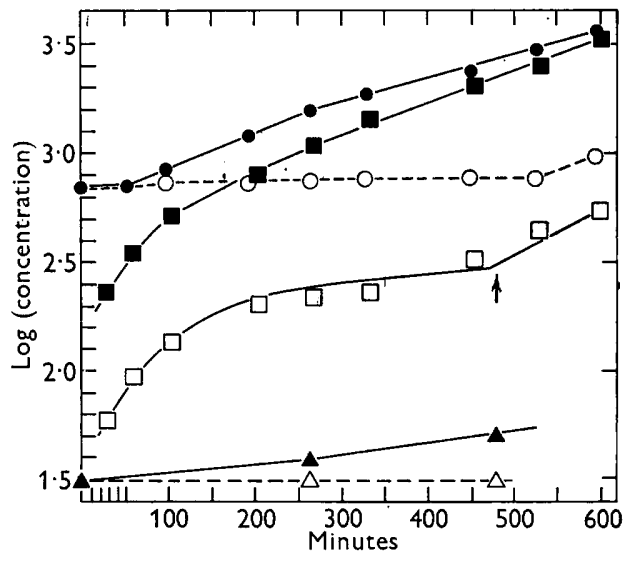

Fig. 4

Fig. 3. Inhibition of the synthesis of photopigments by sulphur starvation. A photosynthetically grown culture on Rhodopseudomonas spheroides was depigmented by a period of aerobic growth. During the experiment the culture was incubated anaerobically in light of $600 \mathrm{ft}$.c. The medium initially contained $0.04 \mu \mathrm{g}$. of ${ }^{35} \mathrm{~S}$ per ml. (as $\left.\mathrm{Na}_{2} \mathrm{SO}_{4}\right)$. Sulphur, m $\mu \mathrm{g} . / \mathrm{ml} ., \square$; bacteriochlorophyll, m $\mu \mathrm{g} . / \mathrm{ml}$., $\mathrm{O}$; carotene, $\mathrm{m} \mu \mathrm{g} . / \mathrm{ml} .,+$.

Fig. 4. Synthesis of bacteriochlorophyll and protein in proline auxotroph in presence and absence of proline. A culture of Rhodopseudomonas spheroides (Ga M7) was grown photosynthetically in a light intensity of $6000 \mathrm{ft} . c$. in medium with proline. After depletion of the endogenous proline the culture was divided into two parts. One part was incubated in the absence of proline (open points) and the other in the presence of proline $(50 \mu \mathrm{g} . / \mathrm{ml}$., filled points). Both cultures were incubated anaerobically in a light intensity of $50 \mathrm{ft} . c$. At the time shown by the arrow L-proline was added to the first culture. Protein, $\mu$ g. $/ \mathrm{ml} ., \Delta$; bacteriochlorophyll, $\mathrm{m} \mu \mathrm{g} . / \mathrm{ml}$., O ; phenylalanine, $\mathrm{m} \mu \mathrm{g} . / \mathrm{ml} ., \square$.

concentration of $0.04 \mu \mathrm{g} . / \mathrm{ml}$. (100,000 c.p.m. $/ \mu \mathrm{g}$.$) and the culture exposed to$ $600 \mathrm{ft} . c$. of light under anaerobic conditions. The results are shown in Fig. 3. The initial specific content of bacteriochlorophyll was $0 \cdot 2 \mu \mathrm{g}$. $/ 100 \mu \mathrm{g}$. of protein and the final value was $2 \cdot 0$.

The specific content eventually attained under these conditions is around $3.0 \mu \mathrm{g} . /$ $100 \mu \mathrm{g}$. of protein.

Experiment 4. In this experiment the proline-requiring mutant was used. The culture was grown anaerobically in bright light (6000 ft.c.), washed once in prolinefree medium and resuspended in the same medium. This suspension was incubated anaerobically in bright light for $2 \mathrm{hr}$. to deplete the proline pool, centrifuged and resuspended in the same medium, and distributed in two growth flasks. To one, L-proline was added to a final concentration of $50 \mu \mathrm{g} / \mathrm{ml}$. Both suspensions were 
incubated anaerobically in dim light ( $50 \mathrm{ft} . c$.$) . At zero time radioactive phenyl-$ alanine was added (3.3 $\mu \mathrm{g} . / \mathrm{ml}$.; 200 c.p.m. $/ \mu \mathrm{g}$.). The results are depicted in Fig. 4. There is no pigment synthesis in the flask without added proline.

Experiment 5. Lascelles has shown that when a culture of Rhodopseudomonas spheroides is suspended in an iron-free medium, synthesis of bacteriochlorophyll ceases and porphyrins are excreted (Lascelles, 1956). It was of interest to see if porphyrins or other intermediates of bacteriochlorophyll synthesis could be detected after the addition of chloromycetin. This was attempted in an experiment similar to Expt. 1. At intervals after the addition of chloromycetin, $25 \mathrm{ml}$. samples were taken, acidified with $\mathrm{HCl}$, centrifuged and the supernatant adjusted to $\mathrm{pH} 3.5$ with sodium acetate. This was extracted with two $15 \mathrm{ml}$. portions of ether and the ether extracted with $4.0 \mathrm{ml}$. of $1.5 \mathrm{M}-\mathrm{HCl}$. No porphyrin could be detected spectrophotometrically in either the original acidified supernatant or in the final hydrochloric acid extract, even $4 \mathrm{hr}$. after the addition of chloromycetin. Also, no porphobilinogen could be detected by the method of Mauzerall \& Granick (1956). Since the rate of bacteriochlorophyll synthesis was approximately $0.5 \mu \mathrm{g} . / \mathrm{ml} . / \mathrm{hr}$. at the time chloromycetin was added, had either porphyrin or porphobilinogen formation continued at this rate, an easily detectable amount would have been present after $4 \mathrm{hr}$. It is concluded that the biosynthesis of bacteriochlorophyll is inhibited at an early stage.

\section{DISCUSSION}

The experiments reported here demonstrate that in the absence of protein synthesis, neither bacteriochlorophyll nor carotenoid pigments are synthesized by cells of Rhodopseudomonas spheroides. Lascelles (1959) reported that chloromycetin as well as $p$-fluorophenylalanine and 8 -azaguanine inhibit the formation of bacteriochlorophyll. The experiments described here have extended this observation. Neither Lascelles's experiments nor those reported here can be interpreted by assuming that the inhibition is due to an inability to form enzymes concerned in bacteriochlorophyll synthesis, since the cultures were synthesizing bacteriochlorophyll before protein synthesis was inhibited.

Two other explanations are possible. In the first, it is assumed that the immediate effect of inhibition of protein synthesis is an increase in the concentration of some metabolite which in turn stops the synthesis of photopigments. It is, however, difficult to see how the formation of both bacteriochlorophyll and carotenoid pigments could be inhibited to the same extent by one compound.

In the second explanation, it is assumed that the synthesis of photopigments cannot proceed independently of the synthesis of the rest of the photosynthetic apparatus. It is interesting to examine some consequences of this hypothesis. The photopigments and some of the enzymes concerned in photosynthesis are associated with the particulate fraction of cell-free extracts of photosynthetic bacteria: the chromatophore fraction. Several analyses of the pigment and protein composition of chromatophores have been published (Cohen-Bazire \& Kunisawa, 1960; Newton \& Newton, 1957; Bergeron, 1959). Table 1 shows some typical results for Rhodopseudomonas spheroides grown under different conditions. The molecular ratio of bacteriochlorophyll to chromatophore protein varies from 1.6 to 11.2 if an average molecular weight of 100,000 is assumed for the protein. Cohen-Bazire has found a 
similar variation in the specific bacteriochlorophyll contents of chromatophore preparations from $R$. rubrum grown in different light intensities. On the other hand, the specific photophosphorylating activity calculated on a protein basis is constant regardless of the light intensity in which the cells were grown (Cohen-Bazire \& Kunisawa, 1960). In other words, these results suggest that cells in different light intensities differ only in their pigment contents.

In order to reconcile this conclusion with the fact that pigment synthesis cannot occur in the absence of protein synthesis the following hypothesis is suggested. It is assumed that the photosynthetic apparatus once formed cannot be modified, and that the amount of pigment associated with a unit of this apparatus depends upon the light intensity at the time the unit is formed. When a culture is subjected to a sudden change in light intensity, the photosynthetic apparatus already present does not change in composition. The chromatophore material subsequently formed will, however, have a different composition determined by the new light intensity; the average chromatophore material will therefore gradually change. Experiments to test this hypothesis further are in progress.

This work was supported in part by a Grant (G-14983) from the National Science Foundation, and in part by a Grant (G-232) from the National Council to Combat Blindness.

\section{REFERENCES}

Bergeron, J. A. (1959). Brookhaven Symposia in Biology, no. 11, p. 118.

Cohen-Bazire, G. \& Kunisawa, R. (1960). Some observations on the synthesis and function of the photosynthetic apparatus in Rhodospirillum rubrum. Proc. Nat. Acad. Sci. Wash. 46, 1543.

Cohen-Bazire, G., Sistrom, W. R. \& Stanier, R. Y. (1957). Kinetic studies of pigment synthesis by non-sulphur purple bacteria. J. cell. comp. Physiol. 49, 25.

Flexer, A. S., Sistrom, W. R. \& Chapman, G. B. (1960). Chromatophore formation in Rhodospirillum rubrum. Bact. Proc. p. 52.

Griffiths, M. \& STANiER, R. Y. (1956). Some mutational changes in the photosynthetic pigment system of Rhodopseudomonas spheroides. J. gen. Microbiol. 14, 698.

Hickman. D. D. \& Frenkel, A. W. (1959). The structure of Rhodospirillum rubrum. J. biophys. biochem. Cytol. 6, 277.

LASCELLES, J. (1956). The synthesis of porphyrins and bacteriochlorophyll by cell suspensions of Rhodopseudomonas spheroides. Biochem. J. 62, 78.

LASCElles, J. (1959). Adaptation to form bacteriochlorophyll in Rhodopseudomonas spheroides: changes in activity of enzymes concerned in pyrrole synthesis. Biochem. $J$. $72,508$.

LASCELLES, J. (1960). The synthesis of enzymes concerned in bacteriochlorophyll formation in growing cultures of Rhodopseudomonas spheroides. J. gen. Microbiol. $23,487$.

Lowry, O. H., Rosebrough, N. J., Farn, A. L. \& Randald, R. J. (1951). Protein measurement with Folin phenol reagent. J. biol. Chem. 193, 265.

Mandelstam, J. (1958). Turnover of protein in growing and non-growing populations of Escherichia coli. Biochem. J. 69, 110.

MaUzerall, D. \& Granick, S. (1956). The occurrence and determination of $\delta$-aminolevulinic acid and porphobilinogen in urine. J. biol. Chem. $219,435$.

Newton, J. W. \& Newton, G. A. (1957). Composition of the photoactive subcellular particles from Chromatium. Arch. Biochem. 71, 250.

Newton, J. W. (1960). Macromolecular variation in the chromatophores of the photosynthetic bacterium Rhodospirillum rubrum. Biochem. Biophys. Acta, 42, 34.

Sistrom, W. R. (1960). A requirement for sodium in the growth of Rhodopseudomonas spheroides. J. gen. Microbiol. 22, 778. 
